\title{
THE DEVELOPMENT OF MISS PPL (ADVANCED MICROSOFT POWER POINT) LEARNING MEDIA AT ELEMENTARY SCHOOL
}

\author{
Liza Auliya ${ }^{1}$, Lazim $\mathbf{N}^{2}$ \\ 1,2 Universitas Riau, Pekanbaru, Indonesia \\ 1yuinqaliza@gmail.com, ${ }^{2}$ lazimpgsd@gmail.com
}

\begin{abstract}
This research aims to develop, know the feasibility test, and see teacher responses and student responses to Miss PPL (Advanced Microsoft Power Point) learning media at elementary school. The media was developed by using Microsoft Power Point 2010 applications. The research method used was a development method with an ADDIE model (Analysis-Design-Develop-Implement-Evaluate). The data obtained were analyzed descriptively quantitative. The result of this study obtained information about the feasibility of the product assessed by the validator from 86.26 with highly feasible category in draft 1 increasing to 95.57 with highly feasible category in draft 2. Teacher response data was 84.38 with a very good category and student responses score 95.89 with a very good category. Based on the result of the research, it can be concluded that Miss PPL learning media (Advanced Microsoft Power Point) developed is suitable for use and increases the diversity of social science learning media, especially in the diversity of Indonesian society.
\end{abstract}

Keywords: miss PPL, social lessons, elementary school

\section{PENGEMBANGAN MEDIA PEMBELAJARAN MISS PPL (MEDIA MICROSOFT POWER POINT LANJUTAN) DI SEKOLAH DASAR}

\begin{abstract}
ABSTRAK
Penelitian ini bertujuan untuk mengembangkan, mengetahui uji kelayakan, serta melihat respon guru dan siswa terhadap media pembelajaran Miss PPL (Media Microsoft Power Point Lanjutan) di Sekolah Dasar. Pengembangan media menggunakan aplikasi Microsoft Power Point 2010. Metode yang digunakan adalah metode pengembangan dengan model ADDIE (Analysis-Design-Develop-Implement-Evaluate). Data yang diperoleh dianalisis secara kuantitatif deskriptif. Hasil penelitian diperoleh informasi kelayakan produk yang dinilai oleh validator sebesar 86.26 dengan kategori sangat layak pada draf 1 meningkat menjadi 95.57 dengan kategori sangat layak pada draf 2. Data tanggapan guru diperoleh skor 84.38 dengan kategori sangat baik dan tanggapan siswa diperoleh skor 95.89 dengan kategori sangat baik. Berdasarkan penelitian tersebut, dapat disimpulkan bahwa media pembelajaran Miss PPL (Media Microsoft Power Point Lanjutan) yang dikembangkan layak untuk digunakan dan menambah variasi media pembelajaran IPS khususnya pada materi keragaman masyarakat Indonesia.
\end{abstract}

Kata Kunci: miss PPL, pembelajaran IPS, sekolah dasar

\begin{tabular}{|c|c|c|}
\hline Submitted & Accepted & Published \\
\hline 21 Mei 2020 & 07 Juli 2020 & 23 Juli 2020 \\
\hline
\end{tabular}

\begin{tabular}{|l|c|c|c|}
\hline Citation & $:$ & $\begin{array}{r}\text { Auliya, L., N. Lazim., \& Guslinda. (2020). The Development of Miss PPL (Advanced Microsoft Power Point) Learning } \\
\text { Media at Elementary School. Jurnal PAJAR (Pendidikan dan Pengajaran), 4(4), 703-714. DOI : } \\
\text { http://dx.doi.org/10.33578/pjr.v4i2.8027. }\end{array}$ \\
\hline
\end{tabular}

\section{PENDAHULUAN}

Bidang pendidikan merupakan industri utama yang mengalami proses transformasi akibat kemajuan dan perkembangan teknologi informasi (Hasibuan, 2014). Inovasi dalam Kurikulum 2013 mendorong guru untuk memiliki kemampuan pedagogik berbasis TIK. Media berasal dari bahasa Latin "Medium" yang berarti "perantara" atau "pengantar" (Mahnun, 2012). Menurut Azhar
Arsyad (2011), media merupakan perantara atau pengantar pesan dari pengirim kepada penerima pesan (Wibawanto, 2017). Penggunaan media dalam pembelajaran memberikan berbagai manfaat seperti meningkatkan motivasi siswa dan informasi yang disampaikan dapat diterima dengan baik oleh siswa (Rasyid, Azis, \& Saleh, 2016). Keabstrakan materi juga dapat 
dikonkretkan melalui media (Djamarah \& Zain, 2013). Media yang digunakan pada penelitian ini adalah Miss PPL (Media Microsoft Power Point Lanjutan) yang termasuk ke dalam media hasil teknologi berbasis komputer.

Miss PPL memaksimalkan penggunaan fitur-fitur yang disediakan power point seperti menambahkan animasi, gambar, suara, dan video yang mendukung penyampaian materi (Kudsiyah \& Harmanto, 2017). Program Power Point merupakan program yang dibuat oleh Microsoft untuk membuat slide atau presentasi (Mustaqim \& Prianto, 2015). Power Point merupakan program aplikasi presentasi di bawah Microsoft Office yang dapat ditampilkan menggunakan LCD proyektor (Sanaky, 2015). Program Aplikasi power point memiliki sejumlah potensi yang dapat dioptimalkan untuk menciptakan kegiatan presentasi yang efektif, efisien, dan menarik seperti penggunaan teks, penggunaan warna, penggunaan gambar atau grafik, penggunaan video, dan penggunaan efek visual (Pribadi, 2017). Power point mempermudah guru dalam mempresentasikan materi ajar kepada siswa.

Penggunaan media hasil teknologi berbasis komputer dapat mengoptimalkan peran komputer sebagai sarana untuk menampilkan dan merekayasa teks, grafik, dan suara dalam sebuah tampilan yang terintegrasi. Media yang akan ditampilkan direncanakan dan dirancang sesuai kebutuhan siswa (Musfiqon, 2015). Menurut (Wati,2016), media pembelajaran berbasis komputer memiliki karakteristik yaitu efektif, menyesuaikan, interaktif, menarik minat, dan terkonsep. Berdasarkan karakteristik tersebut, pengembangan media dilakukan dengan memperhatikan tiga aspek yaitu aspek materi, aspek grafis, dan aspek desain pembelajaran. Aspek-aspek tersebut memuat kriteria yang

\section{METODE PENELITIAN}

Penelitian ini dilakukan di SDN 130 Pekanbaru yang beralamat di Jl. Permadi 1, Delima Kec Tampan Pekanbaru. Penelitian ini dilaksanakan pada semester II (genap) tahun ajaran 2019/2020 yaitu mulai bulan Oktober 2019 Februari 2020. Bentuk penelitian ini adalah dijabarkan dengan indikator-indikator yang yang dikembangkan dari karakteristik media tersebut. Susunan dan desain Miss PPL yang dibuat terdiri dari sampul depan, nama penulis, judul materi, capaian pembelajaran, materi berupa gambar, deskripsi, dan video, petunjuk permainan, LKPD, kesimpulan, evaluasi, dan kata motivasi. Miss PPL dibuat berisikan 22 slide dengan berbagai jenis dan besar huruf.

Miss PPL memuat materi IPS yaitu keberagaman masyarakat Indonesia. Keragaman masyarakat Indonesia merupakan materi pembelajaran IPS siswa kelas IV pada tema 7 (Indahnya Keragaman di Negeriku). Materi ini berisi identifikasi keragaman sosial, ekonomi, budaya, etnis, dan agama di provinsi setempat sebagai identitas bangsa Indonesia serta hubungannya dengan karakteristik ruang. Ilmu Pengetahuan Sosial (IPS) merupakan kajian yang berpusat pada aktivitas kehidupan manusia. Pada tingkat SD, mata pelajaran IPS memuat materi geografi, sejarah, sosiologi, dan ekonomi (Sapriya, 2009). Fokus kajian IPS berupa berbagai aktivitas manusia dalam berbagai dimensi kehidupan sosial sesuai dengan karakteristik manusia sebagai makhluk sosial. Melalui mata pelajaran IPS, siswa diarahkan menjadi warga negara Indonesia yang demokratis, bertanggung jawab, serta cinta damai. Mata pelajaran IPS dirancang untuk mengembangkan pengetahuan, pemahaman, dan kemampuan analisis terhadap kondisi sosial masyarakat dalam memasuki kehidupan bermasyarakat yang dinamis.

Penelitian ini bertujuan untuk mengembangkan, mengetahui uji kelayakan, dan melihat respon guru dan siswa terhadap media pembelajaran Miss PPL (Media Microsoft Power Point Lanjutan) di Sekolah Dasar.

Penelitian pengembangan dengan analisis kuantitatif deskriptif. Penelitian pengembangan merupakan upaya untuk mengembangkan dan menghasilkan suatu produk berupa materi, media, alat, dan lainnya untuk mengatasi pembelajaran di kelas (Tegeh, Jampel, \& Pudjawan, 2015). 
Penelitian ini menggunakan model perancangan media pembelajaran (Instructed Design) tipe ADDIE. Model ADDIE (AnalysisDesign-Develop-Implement-Evaluate) muncul pada tahun 1990-an yang dikembangkan oleh Reiser dan Mollenda. Penelitian pengembangan dengan model ADDIE memiliki rancangan yang dapat digambarkan sebagai berikut.

\section{Gambar 1. Diagram penelitian model ADDIE}

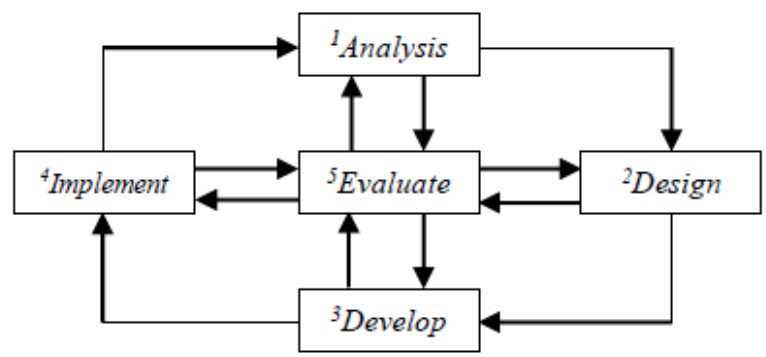

Sumber: (Sari \& Suswanto, 2017)

Sebagai subjek dalam penelitian ini adalah siswa kelas IV SDN 130 Pekanbaru dan sebagai objek yaitu media pembelajaran Miss PPL. Data yang diperlukan dalam penelitian ini adalah data yang diperoleh dari uji validasi, wawancara, dan uji coba produk. Uji validasi dilakukan dengan memberikan angket yang terdiri dari aspek materi, aspek grafis, dan aspek desain pembelajaran kepada validator. Wawancara dilakukan kepada 3 orang siswa dengan 5 pertanyaan. Uji coba produk berupa angket respon guru dan siswa yang terdiri dari aspek tampilan, isi, keterbacaan, dan desain. Validasi media ditentukan oleh nilai rata-rata skor yang diberikan validator dengan skor yang telah ditentukan yaitu 1-4. Pengkategorian penilaian yang akan diberikan validator ditunjukkan pada tabel 1

Tabel 1. Kategori Penilaian oleh Validator

\begin{tabular}{cc}
\hline Skor Penilaian & Kategori \\
\hline 4 & Sangat Baik (SB) \\
3 & Baik (B) \\
2 & Kurang Baik (KB) \\
1 & Tidak Baik (TB) \\
\hline
\end{tabular}

Sumber: (Sugiyono, Metode Penelitian Pendidikan, 2019)

Adapun pedoman perhitungan persentase skor angket validator adalah sebagai berikut:

$$
\mathrm{P}=\frac{\Sigma x}{\Sigma y} \times 100 \% \quad(\text { Sari } \& \text { Suswanto, 2017) }
$$

Keterangan :

$\mathrm{P}=$ persentase kelayakan

$\Sigma \mathrm{x}=$ jumlah keseluruhan jawaban responden

$\Sigma \mathrm{y}=$ jumlah skor maksimal

Untuk menentukan kriteria pengambilan keputusan dalam validasi media, maka perlu dibuat interval dengan langkah-langkah sebagai berikut (Abidin \& Purbawanto, 2015): a. Menentukan pesentase nilai maksimal $=\frac{\text { Skor Maksimal }}{\text { Skor Maksimal }} \times 100 \%$

$=\frac{4}{4} \times 100 \%$

$=100 \%$

b. Menentukan persentase nilai minimal

$=\frac{\text { Skor Minimal }}{\text { Skor Maksimal }} \times 100 \%$

$=\frac{1}{4} \times 100 \%$

$=25 \%$

c. Menentukan range dengan rumus: 

$=$ Persentase nilai maksimal - persentase nilai $=\frac{75 \%}{4}$
minimal

$=100 \%-25 \%$

$=75 \%$

d. Menentukan lebar interval

$=\frac{\text { range }}{\text { jumlah interval }}$
$=18.75 \%$

Kriteria pengambilan keputusan dapat dilihat pada tabel 2 .

Tabel 2. Persentase Kriteria Validitas Media

\begin{tabular}{cc}
\hline Interval rata - rata skor $(\%)$ & Kategori \\
\hline $81.25<$ skor $\leq 100$ & Sangat Layak \\
$62.5<$ skor $\leq 81.25$ & Layak \\
$43.75<$ skor $\leq 62.5$ & Kurang Layak \\
$25<$ skor $\leq 43.75$ & Tidak Layak \\
\hline
\end{tabular}

Sumber : Modifikasi (Sugiyono, Metode Penelitian Pendidikan, 2019)

Setelah divalidasi, media tersebut dilakukan uji coba secara terbatas kepada 30 orang siswa dan seorang guru. Uji coba dilaksanakan di dalam kelas dengan menampilkan media menggunakan proyektor. Setelah media selesai digunakan, siswa dan guru diminta untuk mengisi angket respon terkait media yang telah digunakan. Pengkategorian respon siswa dan guru ditunjukkan pada tabel 3

Tabel 3. Kategori Respon Siswa dan Guru

\begin{tabular}{cc}
\hline Skor Penilaian & Kategori \\
\hline 4 & Sangat Setuju (SS) \\
3 & Setuju (S) \\
2 & Kurang Setuju (KS) \\
1 & Tidak Setuju (TS) \\
\hline Sumber: modifikasi (Sugiyono, Metode Penelitian Pendidikan, 2019)
\end{tabular}

Adapun pedoman perhitungan persentase skor angket respon guru dan siswa adalah sebagai berikut (Sudijono, 2011):

$\mathrm{P}=\frac{f}{\mathrm{~N}} \times 100 \%$

Keterangan:

$\mathrm{P}=$ Angka presentase

$\mathrm{f}=$ skor yang diperoleh responden

$\mathrm{N}=$ Skor maksimal

Tabel 4. Persentase Kriteria Penskoran Respon Guru dan Siswa

\begin{tabular}{cc}
\hline Interval rata - rata skor $(\%)$ & Kategori \\
\hline $81.25<$ skor $\leq 100$ & Sangat Baik \\
$62.5<$ skor $\leq 81.25$ & Baik \\
$43.75<$ skor $\leq 62.5$ & Kurang Baik \\
$25 \quad<$ skor $\leq 43.75$ & Tidak Baik \\
\hline
\end{tabular}

Sumber: (Sugiyono, Metode Penelitian Pendidikan, 2019) 


\section{HASIL DAN PEMBAHASAN}

Penelitian pengembangan media Miss PPL (Media Microsoft Power Point Lanjutan) di Sekolah Dasar diuji coba di SDN 130 Pekanbaru yang beralamat di Jl. Permadi I, Delima Kec Tampan Pekanbaru.

\section{Analisis (Analyze)}

Pada tahap ini dilakukan analisis terhadap kebutuhan, karakteristik siswa dan kurikulum yang digunakan.

a. Analisis kebutuhan

Penulis telah melakukan analisis kebutuhan dalam melakukan pengembangan terhadap media pembelajaran Microsoft Power Point Lanjutan. Berdasarkan observasi di SDN 130 Pekanbaru, sekolah telah memiliki berbagai fasilitas seperti proyektor, speaker, dan beberapa komputer yang dapat digunakan jika dibutuhkan dalam proses pembelajaran.

b. Analisis karakteristik siswa

Analisis karakteristik peserta didik dilakukan untuk mengetahui keterampilan spesifik, pengetahuan awal, gaya belajar, dan sikap peserta didik untuk siap melakukan proses pembelajaran. Analisis ini dilakukan dengan observasi pembelajaran di kelas dan di luar kelas yang dilakukan semasa Pengenalan Lapangan Persekolahan (PLP). Berdasarkan hasil observasi, karakteristik siswa kelas IV SD 130 Pekanbaru adalah senang bermain, senang bergerak, dan senang mempelajari hal baru dan memiliki rasa keingintahuan yang tinggi.

c. Analisis Kurikulum

Analisis kurikulum dilakukan untuk mengkaji kurikulum yang digunakan oleh sekolah tempat uji coba SDN 130 Pekanbaru. Kurikulum yang digunakan adalah Kurikulum 2013. Materi pembelajaran yang dimuat dalam media ini adalah materi IPS kelas IV semester 2 yaitu keberagaman masyarakat pada Tema 7 Subtema 1 Pembelajaran
3.

\section{Desain (Design)}

Pada tahap ini dilakukan proses perancangan media Miss PPL. Dalam perancangan ini ditetapkan bentuk/desain media yang dibuat serta materi yang akan dimuat pada media tersebut. Pemilihan gambar dan video juga dilakukan sesuai dengan materi yang akan dipelajari. Kegiatan yang dilakukan dalam mendesain media adalah: 1) Menyiapkan buku sumber atau buku siswa dan guru kelas IV serta mendownload sumber lainnya yang dirasa perlu; 2) Mengidentifikasi KI, KD, indikator, dan tujuan pembelajaran; 3) Mengumpulkan gambar-gambar, video yang akan mendukung materi; 4) Mendesain Miss PPL.

Media yang akan dibuat terlebih dahulu didesain dengan memasukkan gambar, materi, dan video serta disesuaikan tata letaknya. Media yang didesain terdiri dari beberapa slide yaitu:

\section{1) Slide Pembuka}

Pada slide pembuka terdapat gambar yang mewakili keragaman masyarakat Indonesia, tulisan yang menginformasikan peembelajaran "Tema 7 Subtema 1 Pembelajaran 3", terdapat judul materi "Keragaman Masyarakat Indonesia", kemudian dibawahnya terdapat nama peneliti. Setiap pergantian slide pada media ini dimasukan sound yang telah disesuaikan.

\section{2) Slide Materi}

Slide materi berisi tentang materi-materi pada pembelajaran IPS Tema 7 Subtema 1 pembelajaran 3 sesuai dengan indikator dan tujuan pembelajaran yang ingin dicapai. Dalam halaman materi yang dipelajari terdapat video, gambar, teks, dan animasi. 


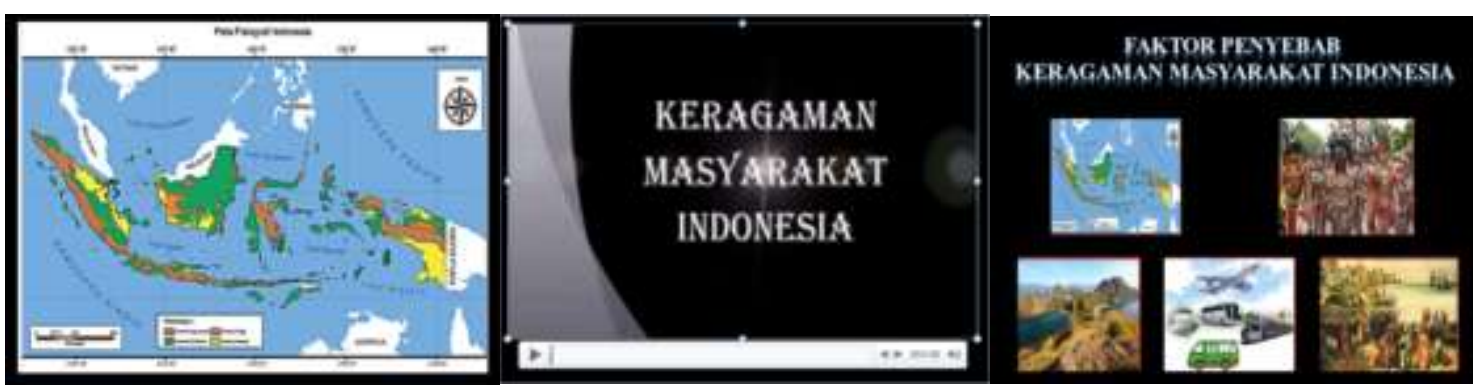

Gambar 2. Slide Materi

3) Slide games ingatan Pada slide game ingatan, siswa ditayangkan petunjuk permainan dan games ingatan pada slide
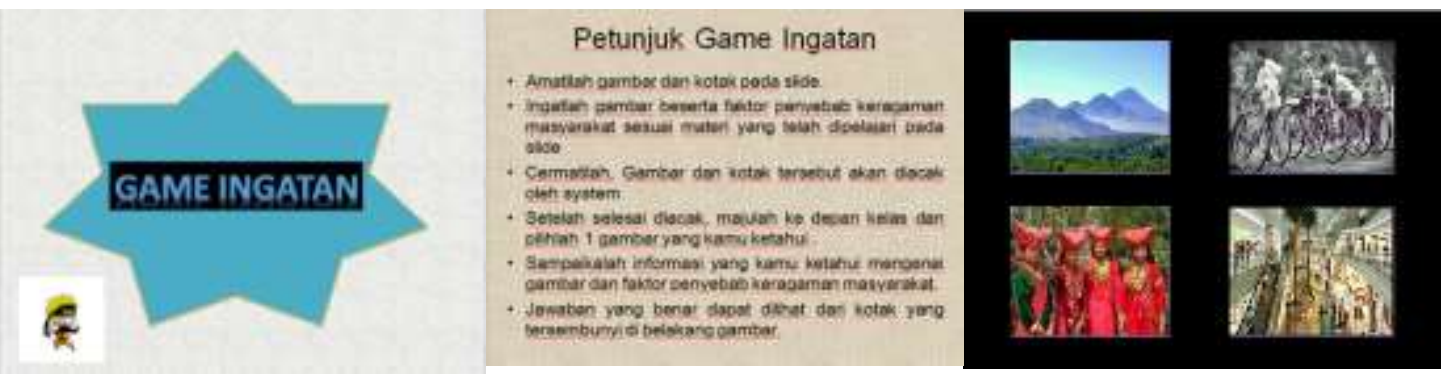

Gambar 3. Slide Games Ingatan

4) Slide LKPD

Slide LKPD di desain dengan

siswa dalam kelompok. Slide LKPD dapat dilihat pada gambar 4 menampilkan 3 kegiatan yang akan dilakukan

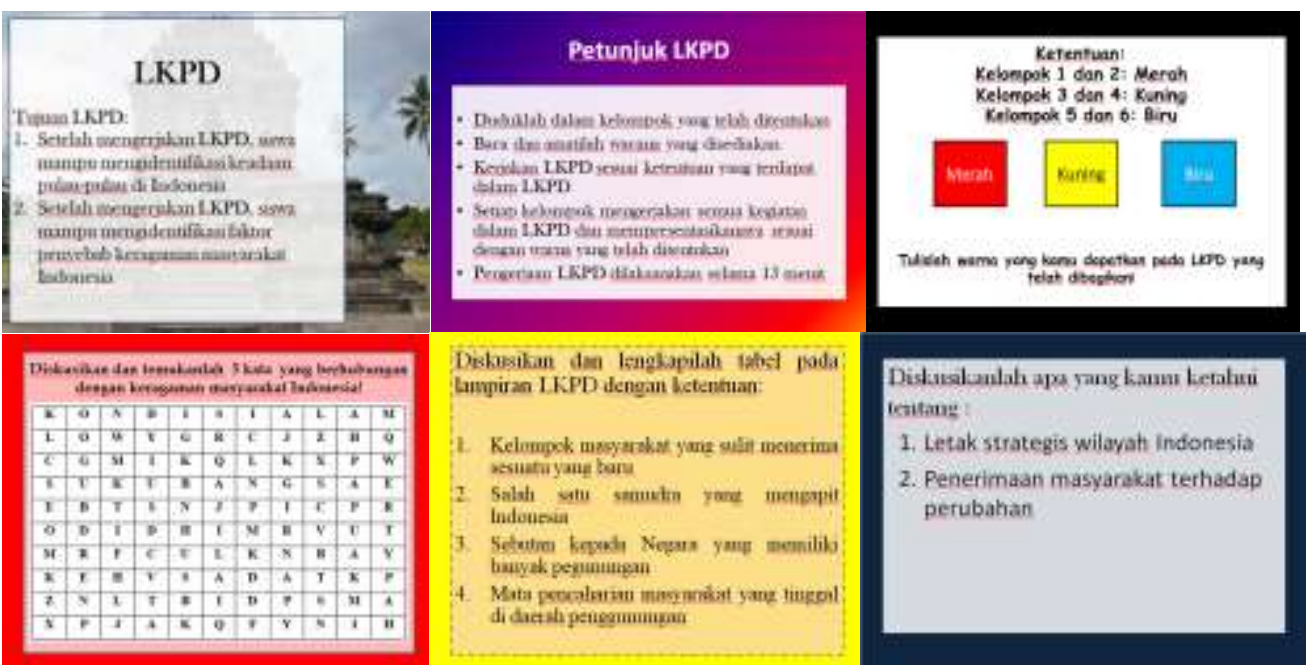

Gambar 4. Slide LKPD 
5) Slide Evaluasi

Pada slide evaluasi, dilakukan pemilihan shapes yang sesuai dan perancangan waktu yang digunakan untuk menjawab soal
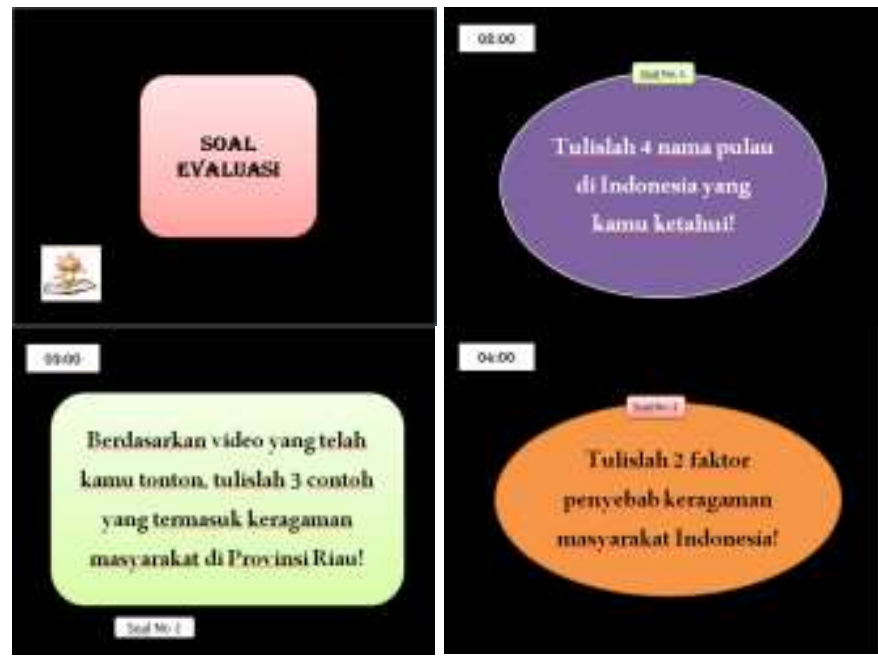

Gambar 5. Slide Evaluasi

\section{Pengembangan (Development)}

Pada tahap ini dilakukan proses pengembangan rancangan produk awal ke dalam produk jadi (Miss PPL), pembuatan instrument validasi media, validasi angket respon guru dan siswa, revisi produk serta revisi angket validasi media dan angket respon. Berikut ini penjelasan pada setiap kegiatan dalam tahap pengembangan media:

a. Pengembangan ke dalam media Miss PPL (Media Microsoft Power Point Lanjutan)

Pada tahap ini, hal-hal yang dilakukan adalah : 1) Mengedit video untuk dimasukkan ke dalam slide; 2) Penggunaan tab animations; 3) Perpaduan tab animations dan home; 4) Pengaturan durasi waktu pada slide soal evaluasi;

5) Mengkreasikan penggunaan tab transition

b. Pembuatan instrument validasi Miss PPL dan angket respon guru dan siswa

Pembuatan instrument validasi media berupa angket dari aspek materi, grafis, dan desain pembelajaran yang berfungsi untuk menilai media Miss PPL yang telah dikembangkan serta mendapat saran dari validator dan melakukan perbaikan. Validasi media pada pengembangan Miss PPL dilakukan oleh Bapak Drs. Zariul
Antosa, M.Sn selaku dosen di Program Studi Pendidikan Guru Sekolah Dasar Fkip UNRI, Ibu Mesnetti, S.Pd dan Ibu Rapika Rahmi, S.Pd selaku guru SDN 130 Pekanbaru. Angket validasi Miss PPL dan angket respon divalidasi oleh Bapak Drs. Zariul Antosa, M.Sn.

\section{c. Revisi produk}

Revisi dilakukan setelah mendapat saran dan komentar dari validator. Hal-hal yang direvisi pada media pembelajaran Miss PPL yaitu: 1) Pada aspek materi indikator 1.1, memperbaiki bahasa yang digunakan dan mencantumkan $\mathrm{KD}$ pada slide; 2) Pada aspek materi indikator 2.2, memperjelas informasi materi pada slide. Pada validasi tahap 1, Miss PPL memuat materi mengenail Kerajaan Hindu Budha di Indonesia. Namun sesuai saran validator, maka materi yang dimuat diubah sesuai dengan materi yang akan dipelajari oleh siswa yaitu materi Keragaman Masyarakat Indonesia pada validasi tahap 2. Pada slide games ingatan, terdapat informasi mengenai faktor penyebab keragaman masyarakat Indonesia. Pada shapes validator menyarankan memuat informasi mengenai gambar dan faktor penyebabnya. Perbaikan dapat dilihat pada gambar 6 dan 7. 


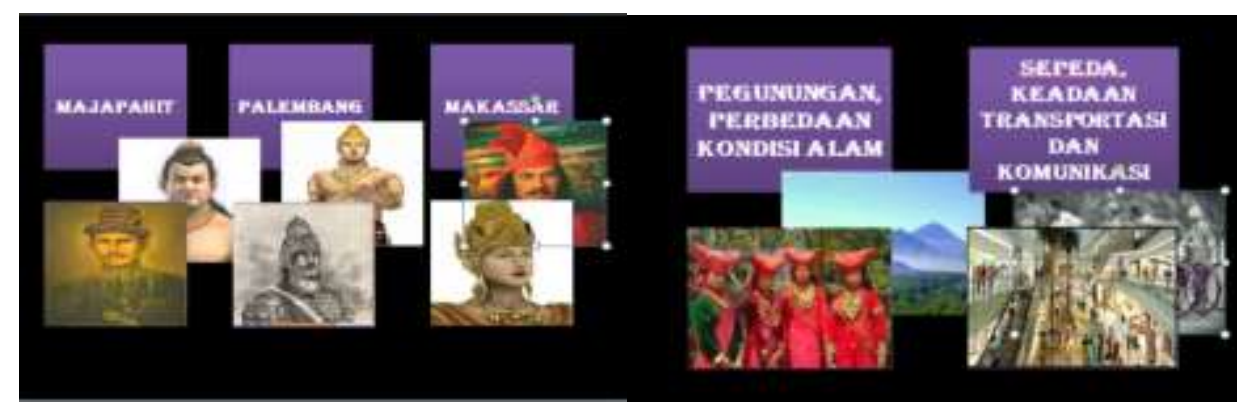

Gambar 6. Sebelum Revisi

Gambar 7. Sesudah Revisi

3) Pada aspek materi indikator 3.1, menyamakan pembagian tugas saat berdiskusi namun pada saat presentasi, kelompok mempresentasikan materi sesuai dengan pembagian yang diperoleh. Revisi dapat dilihat dari slide yang berisi petunjuk LKPD pada gambar 8 dan 9

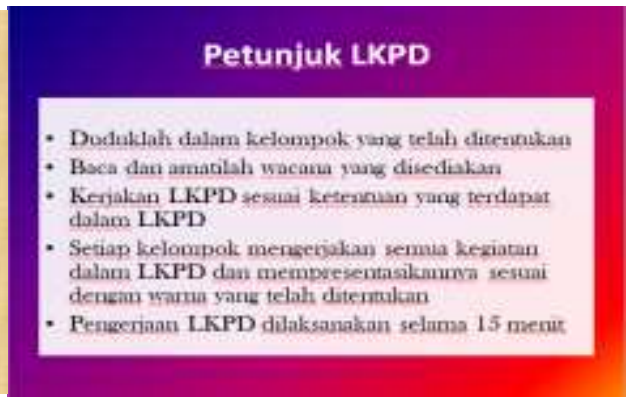

\section{Gambar 9. Sesudah Revisi}

4) Pada aspek grafis indikator 1.1, mengkreasikan tampilan pada slide dengan menggunakan transition secara acak dan beragam sehingga slide memiliki tampilan yang berbeda setiap pergantian. 5) Pada aspek grafis indikator 1.2 dan 4.1, menggunakan type huruf yang sederhana. Pada awalnya peneliti menggunakan type huruf "gabriola" pada slide. Type huruf ini membuat kalimat terlihat seperti tegak bersambung dan agak sulit dibaca oleh siswa. Validator menyarankan pemakaian huruf yang mudah dibaca seperti "times new roman", "Baskerville old face", dan huruf yang mudah dibaca lainnya. Perbaikan dapat dilihat pada gambar 10 dan 11

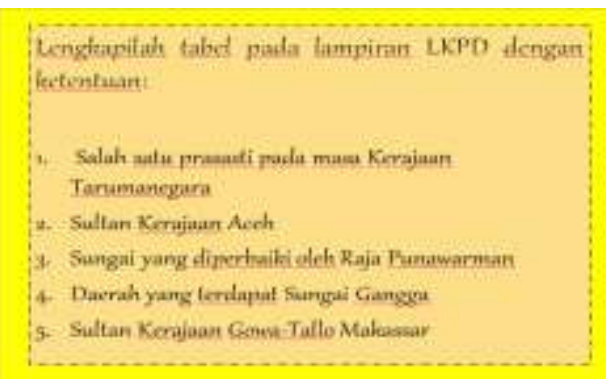

Gambar 10. Sebelum Revisi

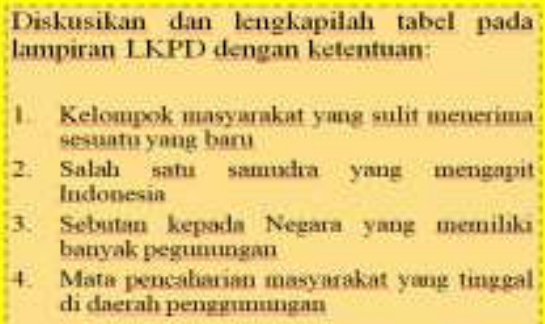

1. Kelcaugok masyarakat yang sulit menerima sestantu yang baru

Salah satu samuktra yang mengapit Indonesin

3. Sebutan kepada Negara yaug menuilika baryak pegumungan

4. Mata pensatiarian masyarahat youg tingeal di daerah pengemungan

\section{Gambar 11. Sesudah Revisi}


6) Pada aspek desain pembelajaran indikator 1.1, menggunakan kombinasi warna yang menarik akan membuat slide tampak lebih hidup. Revisi dilakukan pada beberapa slide yang kebanyakan menggunakan warna hitam dan putih sebagai warna utama diganti dengan warna-warna yang cerah seperti kuning, merah, dan biru. Perbaikan dapat dilihat pada gambar 12 dan 13

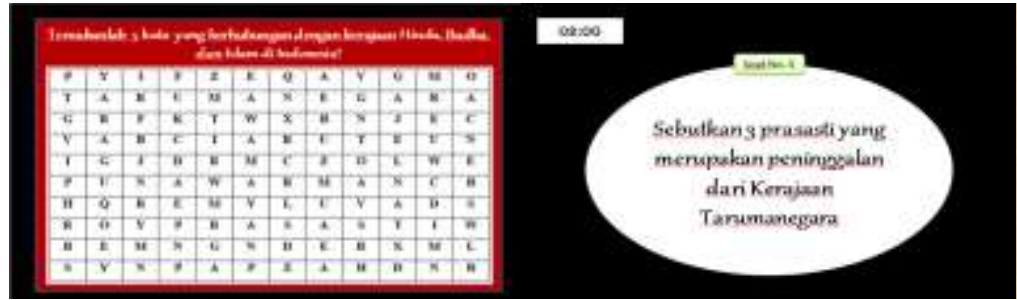

Gambar 12. Sebelum Revisi

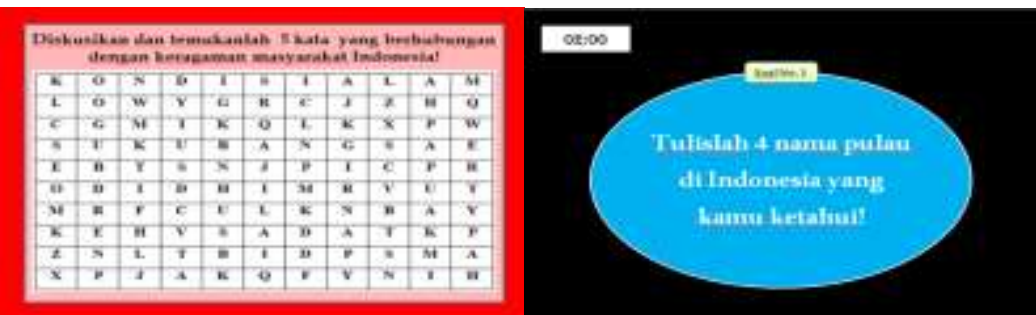

Gambar 13. Sesudah Revisi

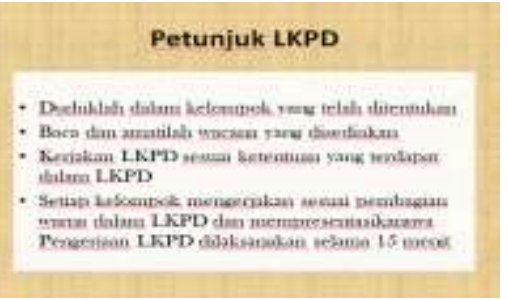

Setelah dilakukan validassi 1 dan validasi

5.

2, maka kelayakan produk dapat dilihat pada tabel

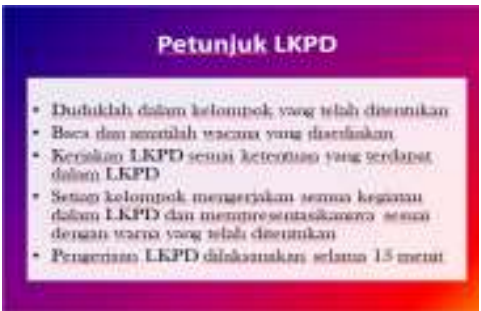

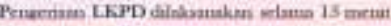

Tabel 5. Data Kelayakan Draf 1 dan Draf 2 perancangan Miss PPL: Media Microsoft Power Point Lanjutan di Sekolah Dasar

\begin{tabular}{llcccc}
\hline No & Aspek Penilaian & \multicolumn{3}{c}{ Rerata Penilaian Validator } \\
& & \multicolumn{2}{c}{ Draf 1 } & Draf 2 \\
& & Persentase & Kategori & Persentase & Kategori \\
\hline 1. & Materi & 87.50 & Sangat Layak & 93.75 & Sangat Layak \\
2. & Grafis & 87.96 & Sangat Layak & 96.30 & Sangat Layak \\
3. & Desain Pembelajaran & 83.33 & Sangat Layak & 96.67 & Sangat Layak \\
\multicolumn{2}{r}{ Total } & 86.26 & Sangat Layak & 95.57 & Sangat Layak \\
\hline
\end{tabular}

\section{Implementasi (Implement)}

Pada tahap implementasi dilakukan uji coba satu satu kepada 3 orang siswa dengan wawancara dan melakukan uji coba terbatas kepada 30 orang siswa. Pada tahap ini implementasi produk dilakukan pada situasi nyata yaitu di kelas (Mulyatiningsih, dalam (Prasetyo, 2018). Siswa sangat senang dan bersemangat ketika pembelajaran berlangsung. Hal ini dapat dilihat dari reaksi dan respon siswa karena belajar dengan Miss PPL merupakan yang pertama mereka alami. Adanya game ingatan pada media membuat siswa sangat bersemangat karena siswa pada tingkat sekolah dasar memiliki karakteristik senang bermain, senang bergerak, senang bekerja dalam kelompok, dan senang merasakan atau melakukan atau memperagakan sesuatu secara langsung (Indriani, 2014).

\section{Evaluasi (Evaluate)}

Pada tahap ini dilakukan dengan metode formatif. Pada evaluasi satu satu, dilakukan 
wawancara kepada siswa kelas IV a dan diperoleh informasi bahwa siswa sangat senang apabila guru menggunakan media ini dalam proses pembelajaran. Uji kelompok kecil dilakukan pada siswa kelas IV b yang berjumlah 30 orang. Pada tahap ini dilakukan uji coba terbatas untuk memperoleh informasi mengenai tanggapan dari guru dan siswa terhadap rangcangan produk yang dikembangkan melalui pemberian angket respon. Data tanggapan guru dapat dilihat pada tabel 6

Tabel 6. Analisis data Tanggapan Guru pada Uji Coba Produk

\begin{tabular}{clcc}
\hline No & \multicolumn{1}{c}{ Aspek } & Skor\% & Kategori \\
\hline $\mathbf{1}$ & Tampilan & 87.50 & Sangat Baik \\
$\mathbf{2}$ & Isi & 83.33 & Sangat Baik \\
$\mathbf{3}$ & Keterbacaan & 75 & Baik \\
$\mathbf{4}$ & Desain & 91.67 & Sangat Baik \\
& Skor Tanggapan Guru & $\mathbf{8 4 . 3 8}$ & Sangat Baik \\
\hline
\end{tabular}

Melalui angket respon siswa, diketahui bahwa Miss PPL merupakan media yang baru bagi siswa dan memiliki tampilan yang menarik dan mendorong siswa untuk aktif dalam belajar. Game ingatan pada media sangat menarik dan melatih kemampuan mengingat siswa. Siswa sangat semangat dan aktif selama belajar dengan media Miss PPL. Analisis data tanggapan siswa dapat dilihat pada tabel 7 di bawah ini:

Tabel 7. Data Tanggapan Siswa pada Uji Coba Terbatas

\begin{tabular}{clcc}
\hline No & \multicolumn{1}{c}{ Aspek } & Skor\% & Kategori \\
\hline $\mathbf{1}$ & Tampilan & 98.33 & Sangat Baik \\
$\mathbf{2}$ & Isi & 95.42 & Sangat Baik \\
$\mathbf{3}$ & Keterbacaan & 93.75 & Sangat Baik \\
$\mathbf{4}$ & Desain & 96.04 & Sangat Baik \\
& Skor Tanggapan Siswa & $\mathbf{9 5 . 8 9}$ & Sangat Baik \\
\hline
\end{tabular}

Selain itu, siswa juga menguasai materi yang disajikan melalui media Miss PPL. Hal itu dibuktikan dengan hasil belajar yang diperoleh

\section{Pembahasan}

Pengembangan Miss PPL sebagai Media Pembelajaran di Sekolah Dasar dilakukan sesuai dengan prosedur pengembangan model ADDIE. Model ADDIE terdiri dari lima tahap yaitu: 1) Analyze (analisis); 2) Design (perancangan); 3) Development (pengembangan); 4) Implementation (pelaksanaan); dan 5) evaluation (penilaian). Pengembangan Miss PPL dimulai dari tahap analisis yang terdiri dari analisis kebutuhan, peserta didik, dan kurikulum. Analisis kebutuhan dilakukan untuk mengetahui ketersediaan fasilitas di sekolah. Analisis karakter siswa dilakukan untuk mengetahui keterampilan spesifik, pengetahuan awal, dan sikap peserta didik untuk siswa. Melalui soal evaluasi yang diberikan, nilai rata-rata yang diperoleh adalah 80.47 dengan delapan orang siswa memperoleh nilai sempurna.

siap melakukan proses pembelajaran. Analisis kurikulum dilakukan untuk mengetahui cakupan materi dan tujuan yang ingin dicapai dari pembelajaran. Lalu mengidentifikasi kompetensi dasar, indikator, dan tujuan pembelajaran melalui silabus. Hal ini dilakukan untuk menyesuaikan materi dan tujuan pembelajaran berdasarkan kompetensi yang dituntut kepada siswa (Prasetyo, 2018). Materi yang dipilih untuk media ini yaitu "Keragaman Masyarakat Indonesia" yang diambil dari buku guru dan buku siswa kelas IV pada tema 7 (Indahnya Keragaman di Negeriku) subtema 1 (Keragaman Suku Bangsa dan Agama di Negeriku) pembelajaran 3. Kemudian pada tahap 
desain peneliti mulai merancang media sesuai dengan tujuan yang telah ditetapkan. Media terdiri dari 22 slide.

Tahap pengembangan dilakukan mulai november 2019. Untuk mengetahui kelayakan media maka dilakukan validasi kelayakan oleh 3 orang validator tang terdiri dari seorang validator ahli dan dua orang validator praktisi. Setelah divalidasi, peneliti melakukan revisi sesuai dari saran validator sehingga Miss PPL layak untuk di ujicobakan secara terbatas pada 30 orang siswa kelas IV SDN 130 Pekanbaru. Hasil validasi tahap 1 dari validator menunjukkan bahwa produk berada pada kategori sangat layak pada setiap aspek, namun karena masih ada beberapa saran dari validator maka dilakukanlah revisi/perbaikan pada media sesuai saran tersebut. Setelah direvisi, dilakukan validasi tahap 2 kepada validator. Pada validasi tahap 2 terjadi peningkatan nilai yang diperoleh pada setiap aspek yaitu 93.75 pada aspek materi, 96.30 pada aspek grafis, dan 96.67 pada aspek desain pembelajaran. Pada tahap pengembangan kerangka yang masih konseptual

\section{SIMPULAN DAN REKOMENDASI}

Pengembangan media pembelajaran Miss PPL pada materi Keragaman Masyarakat Indonesia untuk siswa Sekolah Dasar kelas IV dikembangkan dengan pendekatan research and development $(\mathrm{R}$ \& D) dengan model ADDIE. Pada uji kelayakan media Miss PPL mendapat skor persentase pada validasi pertama yaitu aspek materi sebesar 87.50 kategori sangat layak, aspek grafis sebesar 87.96 kategori sangat layak, dan aspek desain pembelajaran sebesar 83.33 kategori sangat layak. Setelah direvisi sesuai saran validator, maka dilakukan validasi tahap kedua dengan skor pada aspek materi sebesar 93.75 kategori sangat layak, aspek grafis sebesar 96.30 kategori sangat layak, dan aspek desain pembelajaran sebesar 96.67 kategori sangat layak. Rata-rata hasil validasi pada seluruh aspek meningkat dari 86.26 dengan kategori sangat layak pada validasi pertama menjadi 95.57 dengan kategori "Sangat Layak" pada validasi kedua. Respon siswa terhadap Miss PPL yang dikembangkan secara keseluruhan tersebut direalisasikan menjadi produk yang siap diimplementasikan (Mulyatiningsih, 2014).

Pada tahap implementasi dilakukan uji coba satu satu kepada 3 orang siswa dengan wawancara dan melakukan uji coba terbatas kepada 30 orang siswa. Pada tahap ini implementasi produk dilakukan pada situasi nyata yaitu di kelas (Mulyatiningsih, dalam (Prasetyo, 2018). Adanya game ingatan pada media membuat siswa sangat bersemangat karena siswa pada tingkat sekolah dasar memiliki karakteristik senang bermain, senang bergerak, senang bekerja dalam kelompok, dan senang merasakan atau melakukan atau memperagakan sesuatu secara langsung (Indriani, 2014). Lalu untuk mengetahui tingkat kepahaman siswa saat belajar menggunakan Miss PPL, penulis memberikan soal evaluasi dan mendapat hasil yang baik. Pada tahap evaluasi didapati tingginya respon siswa terhadap Miss PPL yaitu 95.89 dengan kategori "sangat baik" dengan rerata hasil belajar 80.47. Respon guru juga mendapat hasil positif yaitu 84.38 dengan kategori "sangat baik"

mendapat skor persentase 95.89 pada kategori "Sangat Baik" dan respon guru sebesar 84.38 pada kategori "Sangat Baik".

Mengacu pada hasil penelitian, peneliti akan memberikan beberapa rekomendasi yang dapat dijadikan sebagai masukan bagi pihak yang terkait. Adapun rekomendasi tersebut ditujukan bagi:

1. Bagi sekolah

Sekolah dapat menyediakan perangkat pendukung agar guru dapat menggunakan media ini dalam proses pembelajaran. Guru dapat menggunakan media pembelajaran MissPPL untuk membantu guru dalam menyampaikan materi pembelajaran kepada siswa.

2. Bagi Peneliti

Peneliti selanjutnya dapat menjadikan penelitian ini sebagai pedoman dan referensi untuk penelitian yang akan datang dan untuk melakukan ujicoba secara luas. 


\section{DAFTAR PUSTAKA}

Abidin, Z., \& Purbawanto, S. (2015). Pemahaman Siswa terhadap Pemanfaatan Media Pembelajaran Berbasis Livewire pada Mata Pelajaran Teknik Listrik Kelas X Jurusan Audio Vidio di SMK Negeri 4 Semarang. Edu Elektrika Jurnal, 4(1). Diakses pada 6 Februari 2020

Djamarah, S. B., \& Zain, A. (2013). Stategi Belajar Mengajar. Jakarta: Rineka Cipta

Hasibuan, Z. A. (2014). Revitalisasi Peran BSNP dalam Peningkatan Mutu Pendidikan Nasional Melalui Pengembangan Standar dan Penyelenggaraan Ujian Nasional yang Kredibel. (T. S. Prihatiningsih, \& dkk, Eds.) 9(3). diakses pada 25 Februari 2020

Indriani, D. S. (2014). Keefektifan Model Think Think Pair Share Terhadap Aktivitas dan Hasil Belajar IPS. Journal of Elementary Education, 3(2). diakses pada 15 Februari 2020

Kudsiyah, S., \& Harmanto. (2017). Pengembangan Multimedia Power Point Interaktif Materi Tata Urutan Peraturan Perundangundangan Nasional Kelas VIIID SMPN 1 Jabon. Jurnal Kajian Moral dan Kewarganegaraan, 5(1). diakses pada 6 Febriaru 2020

Mahnun, N. (2012). Media Pembelajaran. Jurnal Pemikiran Islam, 37(1). diakses pada 12 Februari 2019

Mulyatiningsih, E. (2014). Metode Penelitian Terapan Bidang Pendidikan. Bandung: Alfabeta.

Musfiqon, H. (2015). Pengembangan Media dan Sumber Pembelajaran. Jakarta: Prestasi Pustaka.

Mustaqim, I., \& Prianto, E. (2015). Modul Pelatihan Media Pembelajaran Microsoft Power Point. Yogyakarta: UNY. diakses pada 16 April 2019

Prasetyo, F. (2018). Pengembangan Multimedia Interaktif Berbasis Power Point 2016 pada Subtema 1 Manusia dan Lingkungan Kelas V Sekolah Dasar. diakses pada 13 Februari 2020

Pribadi, B. A. (2017). Media dan Teknologi dalam Pembelajaran. Jakarta: Kencana.
Rasyid, M., Azis, A. A., \& Saleh, A. R. (2016, Februari). Pengembangan Media Pembelajaran Berbasis Multimedia dalam Konsep Sistem Indera pada Siswa Kelas XI SMA. Jurnal Pendidikan Biologi, 7(2). diakses 27 Oktober 2019

Sanaky, H. A. (2015). Media Pembelajaran. Yogyakarta: Safiria Insania Press.

Sapriya. (2009). Pendidikan IPS. Bandung: Rosda.

Sari, H. V., \& Suswanto, H. (2017, Juli). (Sari \& Suswanto, Pengembangan Media Pembelajaran Berbasis Web untuk Mengukur Hasil Belajar Siswa pada Mata Pelajaran Komputer Jaringan Dasar Program Keahlian Teknik Komputer dan Jaringan. Jurnal Pendidikan, 2(7). diakses pada 6 November 2019

Sudijono, A. (2011). Pengantar Evaluasi Pendidikan. Jakarta: Raja Grafindo Persada.

Sugiyono. (2019). Metode Penelitian Pendidikan. Bandung: Alfabeta.

Tegeh, I. M., Jampel, I. N., \& Pudjawan, K. (2015). Pengembangan Buku Ajar Model Penelitian Pengembangan dengan Model ADDIE. Seminar Nasional Riset Inovatif $I V$. diakses pada 28 Oktober 2019

Wati, Ega Rima. 2016. Ragam Media Pembelajaran. Yogyakarta: Kata Pena

Wibawa, S. C., \& dkk. (2017). The Design and Implementation of an Educational Multimedia Interactive Operation System Using Lectora Inspire. Elinvo (Electronics, Informatics, and Vocational Education), 2(1). diakses pada 6 Februari 2020 